Research Article

\title{
Mobile learning student worksheet based on socio- scientific-issues: Enhancing students' scientific literacy skills in biology
}

\author{
Aga Arizen a,1, ${ }^{*}$, S. Suhartini a,2 \\ a Biology Education Department, Graduate Program, Yogyakarta State University, Colombo Street No 1, Karangmalang, Depok, \\ Sleman, the Special Region of Yogyakarta, Indonesia \\ ${ }^{1}$ agaarizen6@gmail.com *; 2 suhartini@uny.ac.id \\ ${ }^{*}$ Corresponding author
}

\begin{tabular}{|c|c|}
\hline ARTICLE INFO & ABSTRACT \\
\hline $\begin{array}{l}\text { Article history } \\
\text { Received February 02, } 2020 \\
\text { Revised February 05, } 2020 \\
\text { Accepted February 20, } 2020 \\
\text { Published march 31, } 2020 \\
\text { Keywords } \\
\text { Mobile learning } \\
\text { Scientific literacy } \\
\text { Socio-scientific-issues } \\
\text { Student worksheet }\end{array}$ & 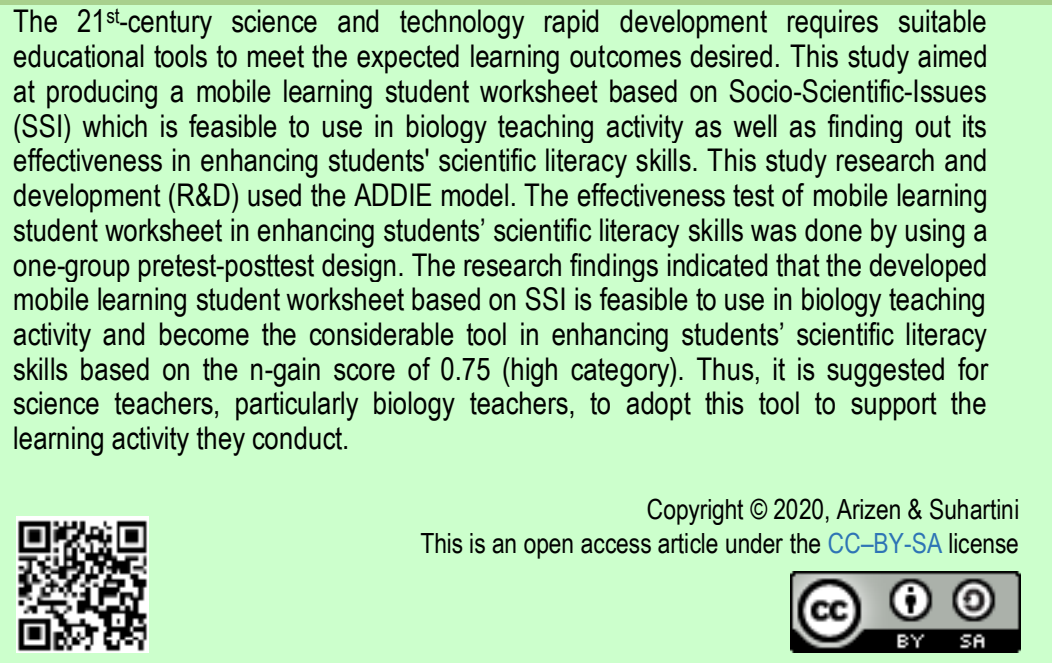 \\
\hline $\begin{array}{r}\text { How to cite: Arizen, A. \& } \\
\text { enhance high } \\
\text { g/10.22219/jp }\end{array}$ & $\begin{array}{l}\text { (2019). Developing mobile learning student worksheet based on socio-scientific-issues to } \\
\text { ants' literacy skill. JPBI (Jurnal Pendidikan Biologi Indonesia), 6(1), 15-24. doi: https://doi.or }\end{array}$ \\
\hline
\end{tabular}

\section{INTRODUCTION}

The $21^{\text {st }}$-century is a century where the industrial world is developing rapidly due to the advances of science and technology to meet human needs. However, the rapid development of industry also raises many problems in various fields including in the environmental field (Kemendikbud, 2017). These problems arise as the consequences of the lack understanding about the importance of science. Human often utilize science and technology by exploiting nature without considering about its impact on the environment and earth future. For instance, the exploitation of natural resources that often causes pollution; deforestation for settlement needs which gives negative impacts on natural balance, and the use of chemicals and technology products in daily life which effects to the abundant of various wastes. Moreover, human often neglect to consider the possible effects, may emerge caused by their behavior, on oneself, family, and the environment. Science understanding which better known as scientific literacy is very important to be mastered by every individual to be able to live 


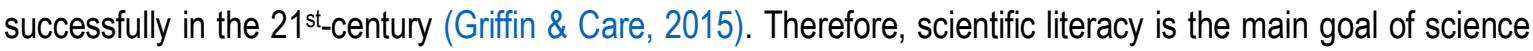
learning today.

Scientific literacy is the ability to use scientific knowledge to identify scientific questions, obtain new knowledge, explain scientific phenomena, and draw conclusions based on evidences in order to understand and help making decisions about nature and its changes due to human activities (OECD, 2015). It means that students who are literate in science will be able to use science concepts in making everyday decisions through process skills; and understand the relationship between science, technology and society; social and economic development and produce useful scientific products (Laugksch, 2000).

Scientific literacy is evaluated internationally by the OECD through the Program for International Student Assessment (PISA). The data reported by PISA showed that the average science score of OECD countries was 489, while Indonesia has only reached the score of 396 and was ranked 69 out of 71 participating countries (OECD, 2019). These results implied that Indonesia has been categorized as the country with low scientific literacy skills. This fact, somehow, showed the need of serious efforts to improve science learning in schools gradually and continuously. One of them is by applying a learning approach and providing more innovative learning tools through the use of current information technology advancements.

Learning approach to improve the ability of scientific literacy can be conducted by inserting scientific issues/phenomena that are close and familiar for students. This approach, in term of Socio-Scientific-lssues (SSI), aims to: (a) make science learning more relevant to the students' life; (b) be a vehicle that directs learning outcomes such as student appreciation of the nature of science; (c) increase the argumentation of students in dialogue; (d) improve students' ability to evaluate scientific data and information; and (e) be an important component in scientific literacy (Sadler \& Zeidler, 2004).

SSI approach can be integrated in learning tools such as student worksheet which is one of essential tool in learning activity. The use of student worksheet helps optimize the involvement or students' activities in learning (Darmodjo \& Kaligis, 1992). Therefore, student worksheet which is integrated with SSI can optimize the activities of students in constructing biological concepts and linking them with scientific issues/phenomena that are relevant to daily life, so that they are expected to be able to improve students' scientific literacy skills.

However, learning tools such as student worksheet must be packaged in an interesting way so that students can linger in learning activities. Unfortunately, student worksheet that are available or published by publishers are generally in printed form and only contain material descriptions and questions to reinforce certain concepts. Thus, the student worksheet does not attract students' interest to participate in the biology learning process optimally, especially to find out scientific issues or phenomena occurred.

The development of Information and Communication Technology (ICT) has encouraged the creation of innovations in all fields (Griffin \& Care, 2015), including in the field of education which is marked by the birth of electronic learning (e-learning). E-learning is a learning activity which utilizes electronic devices. This learning concept makes it easier for students and teachers to obtain learning resources with easy and lightweight access (Mehdipour \& Zerehkafi, 2013). Currently, the concept of e-learning is starting to penetrate and develop into mobile learning that is designed more simply and can answer the deficiencies of e-learning. Mobile learning has practical characteristics Huang, Liao, Huang, and Chen (2013) because it is smaller and lighter than personal computers, it also can be carried anywhere and anytime. Furthermore, it enables more learners to involve as it utilizes technology which commonly used in everyday life.

Based on observations made at SMA Negeri (State Senior High School) 1 Wates, Yogyakarta, it is known that $100 \%$ of students and teachers have mobile device, but they have not been utilized in learning activities. Based on the advantages of mobile learning devices, the more students and teachers who have and use mobile device, the greater the opportunity for the use of mobile learning media in learning activities. Student worksheet which is integrated with SSI approach can be packaged in mobile learning form. By using this learning innovation, it is expected to facilitate students in the learning process as the student worksheet can be accessed anytime and anywhere, both online and offline. In addition, the features in mobile learning makes students are more interested in participating in learning process and socio-scientific-issues contained in student worksheet will make science learning more relevant to students' life, improve students' ability to evaluate scientific data and information, which, in turn, gives the implications to the increase of students' scientific literacy skiils.

Building scientific literacy skills with SSI contextual learning has been previously studied by Presley et al., (2013), Rohmawati, Widodo, and Agustini (2018), Rundgren, Chang, Rundgren, and Johan (2010) who stated that the application of SSI in learning has improved students' scientific literacy skills. The other research conducted by Hwang \& Chang (2011) reported that the use of mobile learning media has increased students' focus and interest in learning. In the other words, it has a positive impact on student learning outcomes. However, the high demand of educational field on the various and relevant learning tools requires more adequate studies about SSI-integrated student worksheet. 
The important of SSI-integrated student worksheet, as its essential role in guiding student learning activities as well as stimulating student learning interest, focus, and participation, has placed this tool to be developed seriously. By gaining information about this research findings, the more various and relevant learning tools can be utilized by teachers and students to ease their learning activities. This also provides for the future researchers the basic information about developing technological-integrated learning tool, so that they can improve better tools in the future. Therefore, the objective of this study was to develop a mobile learning student worksheet based on socio-scientific-issues to enhance high school students' scientific skill.

\section{METHOD}

This study was Research and Development (R \& D) using ADDIE model which consisted of five stages i.e. Analysis, Design, Development, Implementation, and Evaluation. The eligibility of mobile learning student worksheet was evaluated by experts and practitioners. There were three experts evaluated the media (material experts, media experts, and learning experts), meanwhile, the practitioners consisted of biology teachers and senior high school students. The feasibility evaluation of student worksheet, in term of mobile learning was measured using feasibility assessment instrument (Likert scale 1-4) and the assessment results were analyzed based on the assessment system and criteria served in Table 1 (Direktorat Pembinaan SMA, 2010).

Tabel 1. Score interpretation (Quantitative and qualitative data conversion)

\begin{tabular}{cl}
\hline Formula & Criteria \\
\hline $\mathrm{Mi}+1.5 \mathrm{SDi} \leq \mathrm{M} \leq \mathrm{Mi}+3.0 \mathrm{SDi}$ & Very good \\
$\mathrm{Mi}+0 \mathrm{SDi} \leq \mathrm{M} \leq \mathrm{Mi}+1.5 \mathrm{Sdi}$ & Good \\
$\mathrm{Mi}-1.5 \mathrm{SDi} \leq \mathrm{M} \leq \mathrm{Mi}+0 \mathrm{Sdi}$ & Bad \\
$\mathrm{Mi}-3.0 \mathrm{SDi} \leq \mathrm{M} \leq \mathrm{Mi}-1.5 \mathrm{Sdi}$ & Very Bad \\
\hline
\end{tabular}

Mobile learning student worksheet was trialed to the $X$ graders to find out its effectiveness in enhancing scientific literacy skills. The effectiveness of mobile learning student worksheet was tested used one grouppretest-posttest design. The students' scientific literacy skills was measured using an essay test instrument prepared by considering the indicators of the Program for International Student Assessment (PISA) year 2015. Scientific literacy indicators were developed based on aspects of scientific competences, which were (a) explaining phenomena scientifically, (b) evaluate and design scientific inquiry, and (c) interpret data and evidence scientifically. Scientific literacy data were analyzed using paired samples t-test to find out whether there were significant differences of students' scientific literacy skills before and after the use of mobile learning student worksheet. The normality test was done as the assumption test for paired samples t-test.

Furthermore, the increase of scientific literacy skills was analyzed using the technique of normalizing the gain (n-gain score) with the Formula 1 (Hake, 1999):

$<g>=\frac{\mathrm{S}_{\mathrm{f}}-\mathrm{S}_{\mathrm{i}}}{\mathrm{S}_{\max }-\mathrm{S}_{\mathrm{i}}}$

where $\mathrm{S}_{\mathrm{f}}=$ Post-test Score; $\mathrm{S}_{\mathrm{i}}=$ Pre-test $\mathrm{Score}$, and $\mathrm{S}_{\max }=$ Maximum score.

The obtained n-gain scores were interpreted based on the criteria served in Table 2 to see the level of enhancement in students' scientific literacy skills.

Table 2. The criteria of $\mathrm{N}$-gain score interpretation

\begin{tabular}{ll}
\hline Range & Criteria \\
\hline$(<g>)<0.3$ & Low \\
$0.3 \leq(<g>)<0.7$ & Moderate \\
$(<g>) \geq 0.7$ & High \\
\hline
\end{tabular}

\section{RESULTS AND DISCUSSION}

The produced product in this Research and Development was mobile learning student worksheet based on SSI for X graders. Mobile learning student worksheet based on SSI was developed specifically on environmental change topic. The developed mobile learning student worksheet consisted of two main parts which were the homepage and the menu (Figure 1). The menu in the mobile learning student worksheet comprised of (a) Panduan LKPD (the guidelines); (b) Pendahuluan (introduction) which contained of the description of Core Competencies, Basic Competencies, and Learning Indicators which should be achieved by 
students; (c) Peta Konsep (concept map); (d) Kegiatan Pembelajaran (learning activities) which was composed of SSI learning syntax ranging from presenting socio-science issues to reflection; (e) Sumber Belajar (learning resource) which contained learning videos related to environmental change material; (f) Social Network which helps students to connect online to their teacher when they cannot do a face to face; (g) Glosarium (glossary), (h) Test which consisted of scientific literacy and interest in learning tests; (i) Bibliografi (bibliography); and (j) Profil Developer (developer profile). In detail, the mobile learning LKPD (Lembar Kerja peserta Didik/ student worksheet) developed in this study can be seen by downloading the student worksheet application for environmental changes on the Google Play Store.
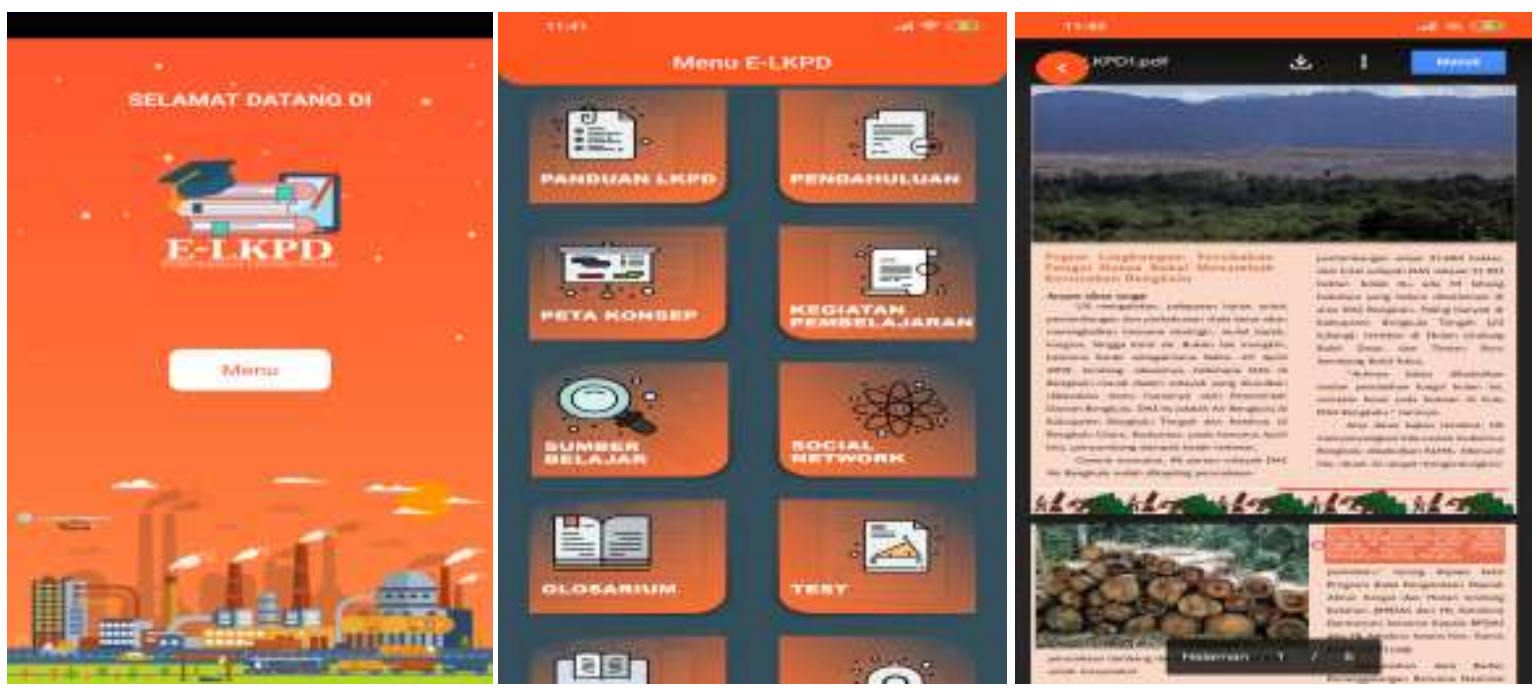

Figure 1. Student worksheet display in mobile learning application

The menu designed as complete as possible to facilitate the students' needs in digging the information about the tool as well as the comprehending the expected learning outcomes they are going to achieve by using the tool. Through this way, the students were desired to achieve their learning goals. It was obviously stated by Montrieux, Vanderlinde, Schellens, and De Marez (2015) that the introduction of certain devices in learning demands a shift in the way students learn, as the device provides interactive, media-rich, and exciting new environments. Thus, the better the design of media, the better the students' manner in using the media.

By considering the user-friendly aspects as the key point of learning media development, the developed mobile learning student worksheet was assessed by experts and practitioners. Assessments by experts were conducted by environmental material experts, media experts, and learning experts, while assessments by practitioners were conducted by biology teachers and high school students. The assessment of material aspects was conducted by one of the environmental experts in Biology Education of Graduate Program in Yogyakarta State University. The material assessment was reviewed based on four aspects consisted of the appropriateness of the material and the accuracy of the material, the presentation of the material, the relevance of the facts to the environmental changes material concept, and language. The results of the assessment of material aspects can be seen in Table 3 .

Table 3. Assessment by material expert

\begin{tabular}{llll}
\hline No & Assessment ascpect & Score & Criteria \\
\hline $1-5$ & Material eligibility and accuracy & 3.80 & Very good \\
$6-14$ & Material presentation technique & 3.11 & Good \\
15 & The relevance of facts and material concepts & 4.00 & Very good \\
$16-18$ & Language & 4.00 & Very good \\
\hline Average & & 3.72 & very good \\
\hline
\end{tabular}

The results of the assessment by environmental material experts implied that the concept of environmental change material and socio-science issues presented in the mobile learning student worksheet are in accordance with Core Competencies, Basic Competencies, and learning indicators that must be achieved by students. The concept of learning was presented clearly. It is arranged from simple to complex, and supported with appropriate pictures and videos. The socio-science issues presented in mobile learning student worksheet is the latest socio-science issues that is taking place or has just happened in the student environment so that it is very relevant to the daily life of students. The language used in explaining the material in mobile learning 
student worksheet is communicative and easy to understand and does not cause ambiguous. Based on Table 3 , the average score of the four aspects given by the material experts is 3.72 , so it can be concluded that the material presented in the mobile learning student worksheet based on SSI is suitable for use in biology learning activities with very good criteria.

An assessment of the media aspects was conducted by the educational technology expert from the Biology Education of Graduate Program in Yogyakarta State University. Media assessments were reviewed based on six aspects i.e. language, the ease of operation, application reliability, illustration quality, and the ease of use. The results of the assessment of material aspects can be seen in Table 4.

Table 4. The assessment results by media experts

\begin{tabular}{llll}
\hline No & Assessment aspect & Score & Criteria \\
\hline $1-4$ & Display quality & 3.75 & Very good \\
5 & Language & 3.00 & Good \\
$6-8$ & Ease of operation & 3.33 & Very good \\
$9-11$ & Application reliability & 4.00 & Very good \\
$12-14$ & Illustration reliability & 3.33 & Very good \\
15 & ease of use & 3.00 & Good \\
\hline Average & & 3.40 & Very good \\
\hline
\end{tabular}

The results of the assessment by media experts depicts that the mobile learning student worksheet developed had an interesting layout/design. Its menu (such as the usage guides, learning activities, learning resources, social networks, glossaries, etc.) was presented creatively. The background color selection, type, size, and font color were appropriate, thereby increasing user readability and the language used in mobile learning LKPD (Lembar Kerja Peserta Didik/student worksheet) was communicative for senior high school students. Moreover, mobile learning student worksheet was very easy to use and has very good compatibility, which was accessible anytime and anywhere. This is one the benefits will be obtained by the learners who utilize mobile learning (Mehdipour \& Zerehkafi, 2013), so that students find their own way to learn (Montrieux et al., 2015), do not have to bring a lot of stacks of books to school. To be more detail, based on Table 4, the average score of the six aspects given by media experts is 3.40 . This is an evidence that the mobile learning student worksheet based on SSI is suitable to use in biology learning activities with very good criteria.

The assessment of learning aspects was conducted by the learning expert from Biology Education of Graduate Program in Yogyakarta State University. This learning assessment was reviewed based on three aspects that are didactive, constructive, and technical. The results of the assessment of learning aspects can be seen in Table 5.

Table 5. The assessment results by the learning expert

\begin{tabular}{llll}
\hline No & Assessment aspect & Score & Criteria \\
\hline $1-8$ & Didaktive & 3.37 & Very good \\
$9-18$ & Constructive & 3.40 & Very good \\
$19-26$ & Technical & 3.50 & very good \\
\hline Average & & 3.42 & Very good \\
\hline
\end{tabular}

The assessment results of learning expert showed that the mobile learning student worksheet had fulfilled the active aspect of presenting environmental issues in accordance with the presented material. It has presented the issues which in accordance with socio-scientific-issues integrated in the mobile learning student worksheet. It also has given the environmental issues which provided the opportunity for students to develop their ability in scientific literacy because students were required to explore further information related to environmental issues and analyze the data and evidence they found in order to make decisions to solve those environmental problems. In this case, mobile learning student worksheet can increase students' understanding and insight, improve their IT and social, moral and aesthetic communication to their surroundings. The improvement of those aspects will occur along with the continuous process in gaining information (Griffin \& Care, 2015), responding the feedbacks given (Yuen Fook \& Nazamud-Din, 2017), and generating new idea (Heong et al., 2012). The construction of mobile learning student worksheet was clearly arranged, simple and used communicative language, SSI syntax integrated in mobile learning student worksheet was clearly detailed. In term of IT, mobile learning student worksheet was easy to operate both for teachers or students. Technically, mobile learning student worksheet has an attractive display of background color selection, the right letters made it easier for users to see the writing or images presented in mobile learning student worksheet. Menu layouts, images, videos, and socio-sciencetific issues were presented in an interesting manner to increase the level of readability by the users. Mobile learning student worksheet was smoothly operated on 
mobile device. Based on Table 5, the average score of the six aspects given by learning expert was 3.42. It means that the tool developed was suitable to be used in the biology learning process with very good criteria.

The assessment of mobile learning student worksheet by biology teacher was conducted by three biology teachers in Senior High School 1 Wates Yogyakarta. The aspects assessed by biology teachers included material/content, language, media and learning. The results of the assessment by biology teachers can be seen in Table 6.

Table 6. The assessment results of biology teachers

\begin{tabular}{llll}
\hline No & Assessment aspect & Score & Criteria \\
\hline $1-4$ & Material/Content & 3.91 & Very good \\
$5-7$ & Language & 3.88 & Very good \\
$8-13$ & Media & 3.77 & Very good \\
$14-20$ & Learning & 3.85 & Very good \\
\hline Average & & 3.85 & Very good \\
\hline
\end{tabular}

The results of the assessment by biology teachers implied that the mobile learning student worksheet was interesting to study, the material presented was in accordance with Core Competencies and Basic Competencies. Student worksheet content was arranged clearly, systematically and covered all learning objectives, and was equipped with relevant and contextual examples. The tool also has an attractive design, easy to operate on android, and used communicative language and was easily understood by students. In term of learning, mobile learning student worksheet helped teachers to present learning in more interesting way to students (Mehdipour \& Zerehkafi, 2013). Moreover, the mobile learning enabled teachers to create learnercentered learning so that the students became more active to participate in each stage of learning activities. As the consequences, the learning activities conducted became more meaningful. It can be inferred that mobile learning student worksheet based on SSI can improve the quality of learning. Based on Table 6, the average score of all aspects given by biology teachers was 3.85 which means that mobile learning student worksheet is feasible to be used in biology learning activities with very good criteria.

The assessment of mobile learning student worksheet by students was conducted by giving questionnaires to 18 of XI graders of SMAN 1 Wates, Yogyakarta. The questionnaire contained statements which were categorized into six aspects, namely, the attractiveness of material and socio-scientific issues, language, the ease of operation/use, attractiveness of mobile learning student worksheet media, flexibility (can be opened anytime and anywhere), and interaction (social network). The results of the assessment by high school students can be seen in Table 7.

Table 7. The assessment results by senior high school students

\begin{tabular}{llll}
\hline No & Assessment aspect & Score & Criteria \\
\hline $1-4$ & Attractiveness of material and scientific issues & 3.42 & Very good \\
5 & Language & 3.44 & Very good \\
$6-8$ & Ease of operation/use & 3.24 & Good \\
$9-13$ & Attractiveness of mobile learning student worksheet media & 3.14 & Good \\
14 & Flexibility (can be opened anytime and anywhere) & 3.50 & Very good \\
15 & Interaction (social network) & 3.00 & Good \\
\hline Average & & 3.29 & Very good \\
\hline
\end{tabular}

The results of the assessment by senior high school students depicts that mobile learning student worksheet based on SSI was interesting to study. The contents in the mobile learning were presented creatively so that they were nor boring for users. The simple material presentation which was supported by concept, maps, pictures, and videos makes it easy to use to understand the material about environmental change. The socio-science issues contained in the learning activities were interesting to discuss. The contextual issues served has led the students to think about learning itself (Hakkarainen, Paavola, Kangas, \& Seitamaa-Hakkarainen, 2015), so that not only did the students learn by memorizing the theory, but they also discussing real problems occurred around students. There were many researchers proofed that contextual learning promotes better students' understanding (Ardianto \& Bambang Priyono, 2014; Dewi et al., 2019; Dewi, Poedjiastoeti, \& Prahani, 2017; Dwianto, Wilujeng, Prasetyo, \& Suryadarma, 2017) about many concepts.

In addition of its contextuality, the developed mobile learning student worksheet has an attractive appearance in terms of various screen color choices, types, and proper font size. Thus, it increased the level of readability for students. Its mobile learning form made it easy for students to learn because it can be accessed via a smartphone, the familiar electronic device for students which is usually carried anywhere and anytime. Hence, students benefited the use of mobile learning as they do not have to carry a lot of books to study (Mehdipour \& Zerehkafi, 2013). Through mobile learning student worksheet, students can also interact/ask teachers about learning through the social network menu when they cannot meet in person. In other words, the 
use of mobile learning student worksheet based on SSI provides a new learning experience that is more interesting for students. Based on Table 7, the average score of all aspects given by students was 3.29, so it can be concluded that the mobile learning student worksheet based on SSI is suitable to be used in learning activities with very good criteria.

The effectiveness test of mobile learning student worksheet based on SSI in enhancing students' scientific literacy skill was conducted on $32 \mathrm{X}$ graders of SMAN 1 Wates Yogyakarta. The effectiveness of the mobile learning student worksheet was proven using paired samples t-test. The results of paired samples t-test analysis can be seen in Table 8.

Table 8. Test result of paired sample t-test

\begin{tabular}{|c|c|c|c|c|c|c|c|c|c|}
\hline & \multicolumn{5}{|c|}{ Paired differences } & \multirow{3}{*}{$\mathrm{T}$} & \multirow{3}{*}{ Df } & \multirow{3}{*}{$\begin{array}{l}\text { Sig. (2- } \\
\text { tailed) }\end{array}$} \\
\hline & & \multirow{2}{*}{ Mean } & \multirow{2}{*}{$\begin{array}{c}\text { Std. } \\
\text { Deviation }\end{array}$} & \multirow{2}{*}{$\begin{array}{c}\text { Std. Error } \\
\text { Mean }\end{array}$} & \multicolumn{2}{|c|}{$95 \%$ Confidence interval of the difference } & & & \\
\hline & & & & & Lower & Upper & & & \\
\hline Pair 1 & $\begin{array}{l}\text { Pre-test - } \\
\text { Post-test }\end{array}$ & $-46,36719$ & 2,89882 & ,51244 & $-47,41232$ & $-45,32205$ & $-90,482$ & 31 & ,000 \\
\hline
\end{tabular}

Table 8 shows that there was significant difference between students' pre-test and post-test score $(\mathrm{t}(31)=$ $90.48, p<0.05)$. This means that the mobile learning developed significantly influenced students' scientific literacy skills. In the other words, it is effective in enhancing students' scientific literacy skills. The magnitude of the increase of students' achievement can be seen based on the N-gain score (presented in Table 9).

\begin{tabular}{llll}
\multicolumn{5}{c}{ Table 9. The results of students' pre-test and post-test } & \\
\hline No & Information & Pre-test & Post-test \\
\hline 1 & Number of students & 32 & 32 \\
2 & Minimum score & 25.00 & 75.00 \\
3 & Maximum score & 56.25 & 97.50 \\
4 & Class average & 38.05 & 84.41 \\
n-gain score & & $\mathbf{0 . 7 5}$ & \\
\hline \multicolumn{2}{l}{ Category of n-gain score } & High \\
\hline
\end{tabular}

Table 9 shows that the average score of the pre-test results was 38.05 , while the average of post-test score was 84.41. Thus, the obtained average of $\mathrm{N}$-gain score was 0.75 . This means that there was an increase of students' scientific literacy skills in the high category after using mobile learning student worksheet based on SSI in learning activities. The distribution of the categories for increasing scientific literacy among 32 students is shown in Figure 2.

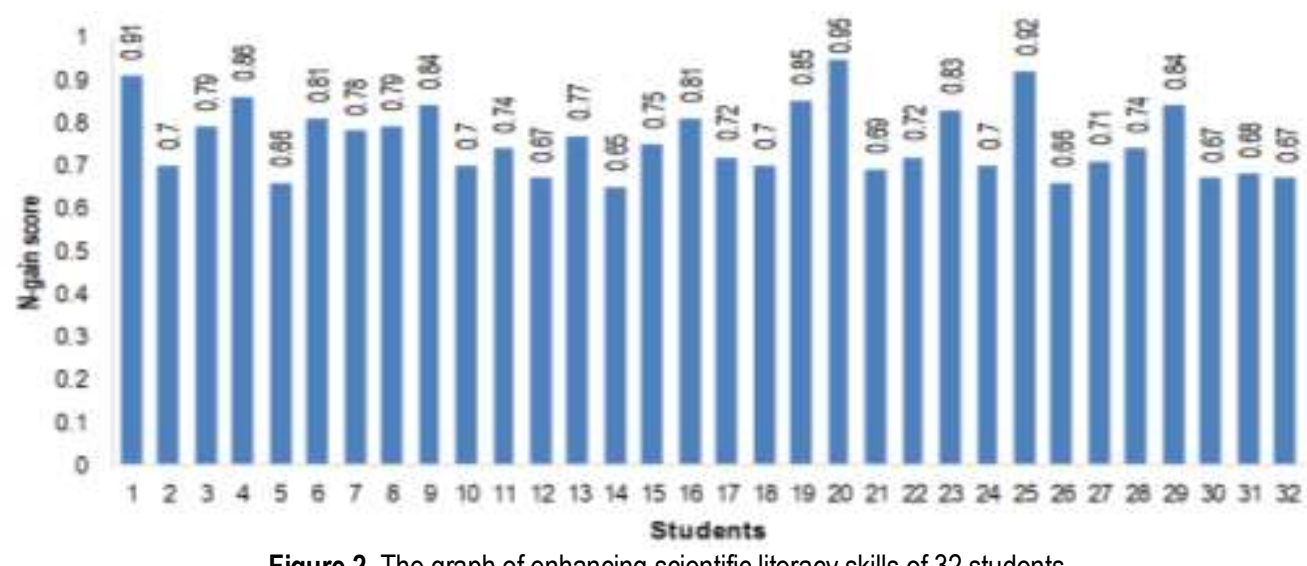

Figure 2. The graph of enhancing scientific literacy skills of 32 students

Based on Figure 2, it can be explained that from the 32 students participated in the research, there were 20 students $(62.5 \%)$ experienced an increase of their scientific literacy skills with a high category. Moreover, the 12 students $(37.5 \%)$ witnessed an increase of their scientific literacy skills in the moderate category. The improvements in each science aspect before and after the use of mobile learning student worksheet based on SSI are presented in Figure 3.

Figure 3 shows that there was an improvement in every aspect of science competences after using mobile learning student worksheet based on SSI in learning activities. The increase in the aspect of explaining scientific phenomena, designing and evaluating scientific investigations, and interpreting scientific data and evidence were $46.68 \%, 43.53 \%$, and $49.84 \%$ respectively. 


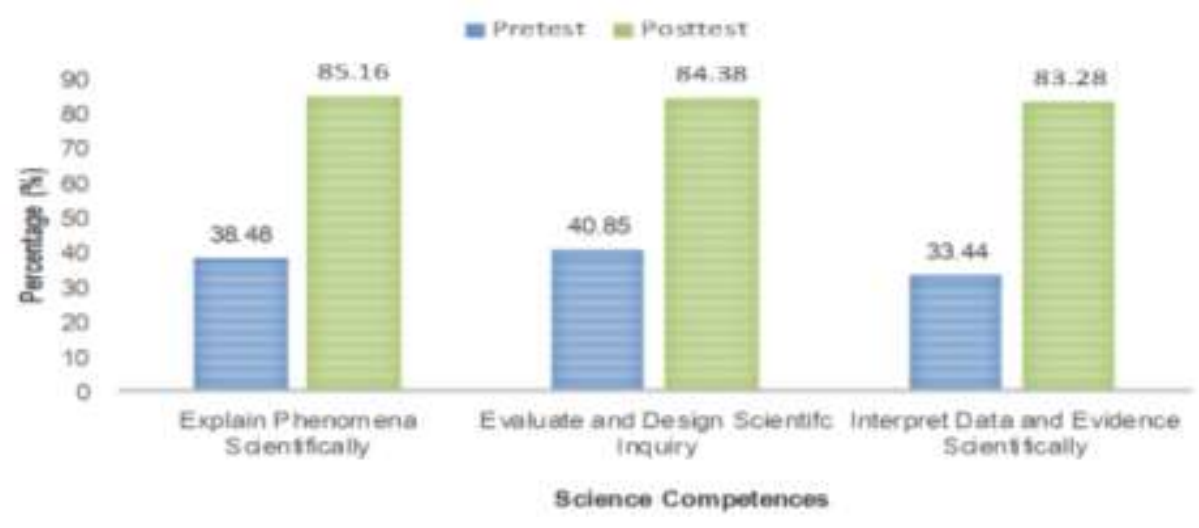

Figure 3. The Graph of enhancement in every aspect of science competences

The mobile learning student worksheet based on SSI is effective in enhancing students' scientific literacy skills because student worksheet is one of the learning tools which helps to optimize the steps of learning activities undertaken by students. The presentation of socio-science issues integrated in the student worksheet helped the students to understand the issues/problems which were happening Zeidler, Sadler, Applebaum, and Callahan (2008) or have just happened in their environment. The presentation of these issues stimulated students to ask about how the environmental issues/problems occur, what are the causes of the phenomena, what if these environmental problems continue to occur, what are the effects and consequences, and so forth. It also encourages students to conduct an investigation, so that they learn how to design a scientific inquiry activities in order to answer the questions generated by themselves. By conducting scientific investigations, the students are encouraged to find various information such as data and evidences related to the presented issues. This, in turn, will improve students' ability to read and interpret the data/information they obtained (Ghani, Ibrahim, Yahaya, \& Surif, 2017). The information and data collected by students are then compiled and discussed to get a conclusion as the basis for argumentation in order to explain the environmental issues/problems which are happening around students. Based on the findings they got through their own investigation, the students can make decisions about what they should do in dealing with or resolving these environmental issues. In other words, the syntax of SSI-based learning is able to improve students' scientific competences.

This is in line with the statement of Presley, et al (2013) who stated that SSI is one of the strong learning strategies in supporting science learning and developing students' scientific literacy skills. The problem of socio-science (climate change, environmental pollution, natural disaster, development of science-based technology, genetics, etc.) is a problem that can only be solved by generations who have good scientific literacy skills. By presenting these socio-scientific issues into learning activities will provide an ideal approach to develop students' scientific literacy skills. Presentation of socio-scientific issues in science learning helps students to gain awareness about the relationship between social, political, and scientific perspectives, through scientific activities such as investigation, reasoning, data and evidence processing, argumentation preparation, and decision making.

Nuangchalerm (2010) in his research also explained that incorporating socio-scientific issues into science learning is important in the science curriculum. Science learning should be stimulated with scientific knowledge that is relevant to everyday life. Presentation of socio-scientific issues in science learning has been proven to be able to improve students' scientific literacy skills. Moreover, Rundgren et al. (2010) and Zeidler, Sadler, Applebaum, and Callahan (2008) suggested that SSI approach provides contextual learning situations that provide an opportunity to develop argumentative scientific skills, exploration of moral issues, as well as to develop moral reasoning and reflective judgment abilities. Through the SSI context, students can find out the impact of the development of science and technology among society. In addition, the argumentation skills developed through SSI approach benefits students' ability to think scientifically or make better decisions, in addition to know the limitations of science and technology. This is in line with the competencies developed in scientific literacy, especially in the aspects of explaining phenomena scientifically.

In addition to integrating SSI into student worksheet, the learning content packaged in the form of mobile learning adds to the students' joy to learn. Notwithstanding that student enjoyment in utilizing learning media is difficult to gain by one-shot treatment (Lin, Lin, Lee, \& Yore, 2014), but it can be triggered by an interesting features of media. The simple presentation of material, the articles package of socio-scientific issues, and the addition of pictures and videos are able to attract the students' interest to the learning concept delivered. This sense of attraction encourages students to keep continue and focused their attention to follow each stage of 
learning activities properly. This is consistent with the research results conducted by (Hwang \& Chang, 2011) who revealed that not only does the use of mobile learning acquire students attention, but it also increases the interaction of students in learning activities. Huang, Liao, Huang, and Chen (2013) and Wishart (2015) also stated that faster access to information, which can be done anywhere and anytime, easy interactions, various learning facility are the advantages of mobile learning utilization. This indicates that mobile learning student worksheet can optimize the learning process so as to improve student learning outcomes.

The other research conducted by Ismail, Permanasari, and Setiawan (2016) revealed that the use of information and communication technology in teaching has strong effect on the level of scientific literacy skills of students. The students who are accustomed in using information and communication technology, often surf the internet, and are confident in basic ICT skills obtain higher scientific literacy scores. Moreover, by doing continuous practices, student learning motivation will be enhanced (Liu, Lin, Jian, \& Liou, 2012).

Based on the explanation above, SSI-based student worksheet which is packaged in the form of mobile learning is a learning innovation that can be used by teachers to enhance the scientific literacy of senior high school students. The presentation of socio-scientific issues according to SSI based on student worksheet is able to train and develop students' scientific competencies. Meanwhile, the packaging in the form of mobile learning increases students' enjoyment and interest in the content being studied. Therefore, it impacts on the enhancing students' scientific literacy skills.

\section{CONCLUSION}

Based on the results of Research and Development, it can be concluded that: (1) the developed mobile learning student worksheet based on SSI is suitable to be used in biology learning activities based on the assessment results of material experts, media experts, and learning experts in which the averages scores gained were 3.72 (very good), 3.40 (very good), and 3.42 (very good) respectively. (2) The developed mobile learning student worksheet based on SSI was positively responded by the users based on the assessment of practitioners with the average score was 3.85 (very good) given by biology teachers and 3.29 (very good) given by senior high school students. (3) The developed mobile learning student worksheet based on SSI is effective in enhancing students' scientific literacy skills based on an average score of $n$ gain 0.75 (high increase category). Hence, the tool developed in this study is recommended to be utilized by biology teachers.

\section{REFERENCES}

Ardianto, A. D., \& Priyono, B. (2014). Penerapan pembelajaran dengan praktikum pembuatan kompos terhadap karakter dan hasil belajar siswa. Unnes Journal of Biology Education, 3(3), 355-363. Retrieved from https://journal.unnes.ac.id/sju/index.php/ujbe/article/view/4536

Darmodjo, H., \& Kaligis, J. R. E. (1992). Pendidikan IPA 2. Jakarta: Departemen Pendidikan dan Kebudayaan. Retrieved from http://library.fip.uny.ac.id/opac/index.php?p=show_detail\&id=6604

Dewi, I. N., Ibrahim, M., Poedjiastoeti, S., Prahani, B. K., Setiawan, D., \& Sumarjan, S. (2019). Effectiveness of local wisdom integrated (LWI) learning model to improve scientific communication skills of junior high school students in science learning. In Journal of Physics: Conference Series. IOP Publishing. doi: http://doi.org/10.1088/1742-6596/1157/2/022014

Dewi, I. N., Poedjiastoeti, S., \& Prahani, B. K. (2017). ELSII learning model based local wisdom to improve students' problem solving skills and scientific communication. International Journal of Education and Research, 5(1), 107-118. Retrieved from https://www.ijern.com/journal/2017/January-2017/09.pdf

Direktorat Pembinaan SMA. (2010). Juknis penyusunan perangkat penilaian afektif di SMA. Jakarta: Direktorat Pembinaan SMA. Retrieved from https://suaidinmath.files.wordpress.com

Dwianto, A., Wilujeng, I., Prasetyo, Z. K., \& Suryadarma, I. G. P. (2017). The development of science domain based learning tool which is integrated with local wisdom to improve science process skill and scientific attitude. Jurnal Pendidikan IPA Indonesia. doi: http://doi.org/10.15294/jpii.v6i1.7205

Ghani, I. B. A., Ibrahim, N. H., Yahaya, N. A., \& Surif, J. (2017). Enhancing students' HOTS in laboratory educational activity by using concept map as an alternative assessment tool. Chemistry Education Research and Practice, 18(4), 849-874. doi: http://doi.org/10.1039/c7rp00120g

Griffin, P., \& Care, E. (2015). Assessment and teaching of 21st century skills. London: Springer Dordrecht Heidelberg. doi: http://doi.org/10.1007/978-94-017-9395-7

Hake, R. R. (1999). Analyzing change/gain scores. Bloomington, USA: American Educational Research Association. Retrieved from https://www. physics.indiana.edu/ sdi/AnalyzingChange-Gain.pdf

Hakkarainen, K., Paavola, S., Kangas, K., \& Seitamaa-Hakkarainen, P. (2015). Sociocultural perspectives on 
collaborative learning. The International Handbook of Collaborative Learning. London: Routledge. doi: http://doi.org/10.4324/9780203837290.ch3

Heong, Y. M., Yunos, J. M., Othman, W., Hassan, R., Tee, T. K., \& Mohamad, M. M. (2012). The needs analysis of learning higher order thinking skills for generating ideas. Procedia - Social and Behavioral Sciences, (59), 197-203. doi: http://doi.org/10.1016/j.sbspro.2012.09.265

Huang, Y. M., Liao, Y. W., Huang, S. H., \& Chen, H. C. (2013). A jigsaw-based cooperative learning approach to improve learning outcomes for mobile situated learning. Educational Technology and Society, 17(1), 128-140. Retrieved from https://www.jstor.org/stable/jeductechsoci.17.1.128

Hwang, G. J., \& Chang, H. F. (2011). A formative assessment-based mobile learning approach to improving the learning attitudes and achievements of students. Computers and Education, 56(4), 1023-1031. doi: http://doi.org/10.1016/j.compedu.2010.12.002

Ismail, I., Permanasari, A., \& Setiawan, W. (2016). STEM virtual lab: an alternative practical media to enhance student's scientific literacy. Jurnal Pendidikan IPA Indonesia, 5(2), 239-246. doi: http://doi.org/10.15294 /jpii.v5i2.5492

Kemendikbud, T. G. (2017). Panduan gerakan literasi nasional. (L. A. Myani, Ed.). Jakarta: Kementrian Pendidikan dan Kebudayaan. Retrieved from https://gln.kemdikbud.go.id/glnsite

Laugksch, R. (2000). Scientific literacy: A conceptual overview. Science Education, 84(1). doi: http://doi.org/ 10.1002/(SICl)1098-237X(200001)84

Lin, S., Lin, H., Lee, L., \& Yore, L. D. (2014). Are science comics a good medium for science communication? The case for public learning of nanotechnology. International Journal of Science Education, (May 2015), 37-41. doi: http://doi.org/10.1080/21548455.2014.941040

Liu, E. Z. F., Lin, C. H., Jian, P. H., \& Liou, P. Y. (2012). The dynamics of motivation and learning strategy in a creativity-supporting learning environment in higher education. Turkish Online Journal of Educational Technology, 11(1), 172-180. Retrieved from http://tojet.net/articles/v11i1/11116.pdf

Mehdipour, Y., \& Zerehkafi, H. (2013). Mobile learning for education: benefits and challenges. International Journal of Computational Engineering Research, 3(6), 93-101. doi: http://doi.org/10.1080/87567555.20 11.604802

Montrieux, H., Vanderlinde, R., Schellens, T., \& De Marez, L. (2015). Teaching and learning with mobile technology: A qualitative explorative study about the introduction of tablet devices in secondary education. PLOS ONE, 10(12), 1-17. doi: http://doi.org/10.1371/journal.pone.0144008

Nuangchalerm, P. (2010). Engaging students to perceive nature of science through Socioscientific IssuesBased Instruction. European Journal of Social Sciences, 13(1), 34-37. Retrieved from https://files.eric. ed.gov/fulltext/ED508531.pdf

OECD. (2015). OECD Economic surveys: Brazil. OECD. doi: http://doi.org/10.1787/eco_surveys-jpn-2009-en

OECD. (2019). PISA 2018 insight and interpretations. OECD. Retrieved from https://www.oecd.org/pisa

Presley, M. L., Sickel, A. J., Muslu, N., Johnson, D. M., Witzig, S. B., Izci, K., \& Sadler, T. D. (2013). A framework for socio-scientific issues based education. Science Educator, 22(1). Retrieved from https:l /files.eric.ed.gov/fulltext/EJ1062183.pdf

Rohmawati, E., Widodo, W., \& Agustini, R. (2018). Membangun kemampuan literasi sains siswa melalui pembelajaran berkonteks Socio-Scientific Issues berbantuan media weblog. Jurnal Penelitian Pendidikan IPA, 3(1). doi: http://doi.org/10.26740/jppipa.v3n1.p8-14

Rundgren, Chang, S.-N., Rundgren, \& Johan, C. (2010). SEE-SEP: From a separate to a holistic view of socio-scientific issues. Asia-Pacific Forum on Science Learning and Teaching, 11(1), 1-24. Retrieved from http://journaldatabase.info/articles/see-sep_from_separate_holistic_view.html

Sadler, T. D., \& Zeidler, D. L. (2004). The morality of socioscientific issues: Construal and resolution of genetic engineering dilemmas. Science Education, 88(1), 4-27.doi: http://doi.org/10.1002/sce.10101

Wishart, J. (2015). Assimilate or accommodate? The need to rethink current use of the term "Mobile learning." In The Mobile learning voyage - From small ripples to massive open waters (pp. 229-238). Springer, Cham. doi: http://doi.org/10.1007/978-3-319-25684-9_17

Yuen Fook, C., \& Nazamud-Din, A. (2017). Strategies to enhance assignment and feedback practices in the 21st century classroom: A case study. Pertanika Journal of Social Science and Humaniora, 25, 155166. Retrieved from http://www.myjurnal.my/public/article-view. php?id=112451

Zeidler, D. L., Sadler, T. D., Applebaum, S., \& Callahan, B. E. (2008). Advancing reflective judgment through socioscientific issues. JRST, 46(1), 74-101. doi: http://doi.org/10.1002/tea.20281 